\title{
Masculinity and Health - How Gender Shapes Male Attitudes towards Health
}

\author{
Terri Juneau \\ Texas Woman's University \\ United States
}

\section{Introduction}

When I get a cold, I typically go to a doctor if it gets too bad. If my husband gets a cold, he simply downplays it and remains sick for about three weeks as the cold turns into the flu. When that happens, he will simply say "I'll drink a lot of orange juice and be fine" and the flu turns into pneumonia and I drag him, unwillingly, to urgent care. What happens though when there isn't a me to drag a man kicking and screaming to the doctor?

Nothing. This is the norm now for males across the globe, of various ages, from all walks of life and varying backgrounds and ethnicities and race. Males are simply not going to the doctor. They aren't seeking help for physical ailments; they are not getting screened for male-only diseases and they are most certainly not reaching out for mental health and illnesses. This is not just a societal problem; this is an epidemic of mass proportions. A big reason for this mass boycott of health provision is the way men view disease and how that links up with their own ideas of masculinity. It is not masculine to be weak or to ask for help. As a society we have reinforced what it is to be masculine by creating gender norms and roles. That has ledto fragile masculinity, or hegemonic masculinity, which is an overcompensation of masculinity which leads to destructive health behaviors and devastating outcomes to problems that could potentially be solved with a simple doctor visit.

\section{Methodology}

This research paper was done using a systematic review of literature found through the TWUniversal library system. Using the search term "constructions of masculinity" and "health" I got this many results. I then expanded beyond the library results to get this many results. I then applied the following filters: Peer-reviewed, Full-text only and got this many results. I also used the search term "masculinity and health" on the same website for a new search. I received 117,290 results. I then expanded beyond the library collection to get 140,593 results. I then applied the following filters: Peer-reviewed, full-text and this time I set a date range of 2010 to present. This left me with 55,972 results. I decided to not exclude studies and research done from outside the United States, as I think male health is something that is a global issue. I then decided to include some studies that are older as I found that the findings were still relevant today.

\section{Discussion}

About $75 \%$ of the research geared towards males and health looks towards mental health, not physical health (Affleck, Carmichael, and Whitley 2018; Apesoa-Varano, Barker, and Hinton 2018; Gast and Peak 2011; Hoy 2012; Kimmel and Mahler 2003; Kumpula and Ekstrand 2014; Mahalik et al. 2005; Möller-Leimkühler 2002). This could be due to a shift in men's studies programs, as the research states that males are becoming far more likely to suffer from a mental breakdown or illness such as substance abuse, manic rage episodes and depression; they also have the highest rate for suicide (Affleck, Carmichael, and Whitley 2018). Physical health, while not as focused on, was also represented in the literature when seeking out male health (Addis and Mahalik 2003; Annandale and Hunt 1990; Courtenay 2011; Galdas, Cheater, and Marshall 2005; Mansfield, Addis, and Mahalik 2003; Sloan, Conner, and Gough 2015; Tannenbaum and Frank 2011), though not as plentiful nor recent. Males are underreported in both mental and physical health even though they are far more likely to suffer a chronic illness and typically die 7 years before women (Courtenay 2000). When addressing why this is the case, the answer to both sides of mens' health was the same: Men aren't seeking help because that is not what they are taught to do (Addis and Mahalik 2003; Courtenay 2000). All of the things one must possess to seek help either on a mental or on a physical level are feminine traits, not masculine ones. If we think about what must occur in order to get help, actions such as disclosure of illness, depending on others, and vulnerability are all competing with what males are taught from early on. They are taught that they must be strong, self-reliable and manly and are societally awarded for not reporting illnesses and not appearing as weak (Annandale and Hunt 1990). When looking at mental illness especially, men are reporting that their depression is linked to fragile masculinity (ApesoaVarano, Barker, and Hinton 2018) and that losing a job, getting an illness or going through a divorce made them feel like they lost their status as a man. The literature as a whole only highlights the role of hegemonic masculinity when looking at mental health such as depression and suicide. 
Males are far more likely to develop risky behaviors like smoking and alcohol abuse due to how society has constructed its idea of what it means to be "masculine" (Courtenay 2000). If you really want to "be a man" you put yourself at great risk of disease, injury or death due to masculine ideals of hegemonic masculinity (Courtenay 2011). Things such as physical fighting, not being able to control anger and avoiding health screenings are all risky behavior that are deemed "traditionally masculine" by most cultures (Gast and Peak 2011).

This overcompensation to appear "manly" also leads to detrimental actions like school shootings (Kimmel and Mahler 2003), as the adolescent males involved typically are bullied and feel feminized. Males perceive this as a loss of power (Kumpula and Ekstrand 2014) and in return overcompensate. Highly masculine men hide emotions they should be feeling, so health questionnaires that are typically self-reported lack reliability (Moynihan 1998). This is not just an American issue; a study was done that looked at six focus groups of boys aged 13 to 17 in Indonesia and in that study smoking was equated with masculinity ( $\mathrm{Ng}$, Weinehall, and Öhman 2006). A quantitative study from the United Kingdom found that males with high masculinity traits scored higher on negative health behaviors (Sloan, Conner, and Gough 2015). Mexican males are culturally taught to use machismo when looking at health behaviors (Sobralske 2006) and do not seek help.

These behaviors are not relegated to an age within the male gender. When looking at older males, they will only seek help if it conflicts with hegemonic attitudes like dependence (Tannenbaum and Frank 2011) and suicide is typically higher among older males (Apesoa-Varano, Barker, and Hinton 2018). Younger males are underreported when looking at sexual health resources and have a tougher time communicating when it comes to sexual problems; they use masculine scripts in which they have all the power when it comes to sex (Knight et al. 2012) therefore creating "locker room talk." This also is not just a straight male problem. Even among gay males hegemonic attitudes are prevalent and anti-effeminacy beliefs are the norm due to the hegemonic attitude that men are superior to women (Taywaditep 2002). "Bottoms" in gay culture are deemed more feminized in sexual acts. When looking at some of the most extreme hegemonic behavior, males who are injured in combat were interviewed and the research shows that themes such as maintenance of social capital, being able to remain in the field and the risk of not being rewarded for hegemonic masculinity all played a part in their delayed health help (Cogan, Haines, and Devore 2019).

\section{Conclusion}

Regardless of age, ethnicity, sexual preference or background there is a trend in healthcare among men of delayed or missing help seeking behavior (Galdas, Cheater, and Marshall 2005). Masculinity negatively impacts both mental health and physical health of men (Hoy 2012). Males who conform to masculine beliefs have greater benefits than males who seek help due to society's construction of gender (Mahalik et al. 2005; Möller-Leimkühler 2002). Very few of the studies gave remedies for the issue. The only clear cut remedy given was to defeminize the health care system but no instructions to how that would be done were given (Affleck, Carmichael, and Whitley 2018). Further research should be done on how to fix male health instead of causes of male health, as the cause is clearly masculinity.

\section{References}

Addis, Michael E., and James R. Mahalik. 2003. "Men, Masculinity, and the Contexts of Help Seeking." American Psychologist 58(1):5-14. doi: 10.1037/0003-066X.58.1.5.

Affleck, William, Victoria Carmichael and Rob Whitley. 2018. "Men's Mental Health: Social Determinants and Implications for Services." Canadian Journal of Psychiatry. Revue Canadienne De Psychiatrie 63(9):581-589 (https://www.ncbi.nlm.nih.gov/pubmed/29673270). doi: 10.1177/0706743718762388.

Annandale, Ellen, and Kate Hunt. 1990. "Masculinity, Femininity and Sex: An Exploration of their Relative Contribution to Explaining Gender Differences in Health." Sociology of Health \& Illness 12(1):24-46 (https://onlinelibrary.wiley.com/doi/abs/10.1111/1467-9566.ep10844865). doi: 10.1111/1467-9566.ep10844865.

Apesoa-Varano, Ester C., Judith C. Barker and Ladson Hinton. 2018. "'If You were Like Me, You would Consider it Too": Suicide, Older Men, and Masculinity." Society and Mental Health 8(2):157-173 (https://journals.sagepub.com/doi/full/10.1177/2156869317725890). doi: 10.1177/2156869317725890.

Cogan, Alison M., Christine E. Haines and Maria D. Devore. 2019. "Intersections of US Military Culture, Hegemonic Masculinity, and Health Care among Injured Male Service Members." Men and Masculinities:.doi: 10.1177/1097184X19872793.

Courtenay, Will H. 2000. "Constructions of Masculinity and their Influence on Men's Well-being: A Theory of Gender and Health." Social Science \& Medicine 50(10):1385-1401 
(https://www.sciencedirect.com/science/article/pii/S0277953699003901). doi: 10.1016/S0277-9536(99)003901.

Courtenay, Will H. 2011. Dying to be Men.Taylor and Francis.

Galdas, Paul M., Francine Cheater and Paul Marshall. 2005. "Men and Health Help-seeking Behaviour: Literature Review." Journal of Advanced Nursing 49(6):616-623 (https://onlinelibrary.wiley.com/doi/abs/10.1111/j.1365-2648.2004.03331.x). doi: 10.1111/j.1365-2648.2004.03331.x.

Gast, Julie, and Terry Peak. 2011. "'It used to be that if it Weren'T Broken and Bleeding Profusely, I would Never Go to the Doctor": Men, Masculinity, and Health." American Journal of Men's Health 5(4):318-331 (https://www.ncbi.nlm.nih.gov/pubmed/20798142). doi: 10.1177/1557988310377926.

Hoy, Sandra. 2012. "Beyond Men Behaving Badly: A Meta-Ethnography of Men's Perspectives on Psychological Distress and Help Seeking." International Journal of Men's Health 11(3):202-226 (https://search.proquest.com/docview/1282107757). doi: 10.3149/jmh.1103.202.

Kimmel, Michael S., and Matthew Mahler. 2003. "Adolescent Masculinity, Homophobia, and Violence." American Behavioral Scientist 46(10):1439-1458 (https://journals.sagepub.com/doi/full/10.1177/0002764203046010010). doi: 10.1177/0002764203046010010.

Knight, Rod, Jean A. Shoveller, John L. Oliffe, Mark Gilbert, Blye Frank and Gina Ogilvie. 2012. "Masculinities, 'guy Talk' and 'manning Up': A Discourse Analysis of how Young Men Talk about Sexual Health." Sociology of Health \& Illness 34(8):1246-1261

(https://onlinelibrary.wiley.com/doi/abs/10.1111/j.1467-9566.2012.01471.x). doi: 10.1111/j.14679566.2012.01471.x.

Kumpula, Esa, and Per Ekstrand. 2014. "Challenges and Possibilities for Understanding Men's Health in Twenty-First Century Forensic Psychiatric Care." Issues in Mental Health Nursing 35(8):613-619 (http://www.tandfonline.com/doi/abs/10.3109/01612840.2014.881441). doi: 10.3109/01612840.2014.881441.

Kvigne, Kari, MaritKirkevold, Randi Martinsen and Berit A. Bronken. 2014. "Masculinity and Strokes: The Challenges Presented to Younger Men by Chronic Illness." Journal of Gender Studies 23(2):197-210 (http://www.tandfonline.com/doi/abs/10.1080/09589236.2013.790797). doi: 10.1080/09589236.2013.790797.

Mahalik, James R., W. T. Talmadge, Benjamin D. Locke, Ryan P. J. Scott and Aaron B. Rochlen. 2005. "Using the Conformity to Masculine Norms Inventory to Work with Men in a Clinical Setting." Journal of Clinical Psychology 61(6):661-674 (https://onlinelibrary.wiley.com/doi/abs/10.1002/jclp.20101). doi: 10.1002/jclp.20101.

Mansfield, Abigail K., Michael E. Addis and James R. Mahalik. 2003. "'Why Won'T He Go to the Doctor?": The Psychology of Men's Help Seeking." International Journal of Men's Health 2(2):93-109 (https://search.proquest.com/docview/222853737). doi: 10.3149/jmh.0202.93.

Möller-Leimkühler, Anne M. 2002. "Barriers to Help-Seeking by Men: A Review of Sociocultural and Clinical Literature with Particular Reference to Depression." Journal of Affective Disorders 71(1):1-9.

Moynihan, Clare. 1998. "Theories of Masculinity." Bmj 317(7165):1072 (http://dx.doi.org/10.1136/bmj.317.7165.1072). doi: 10.1136/bmj.317.7165.1072.

Ng, Nawi, L. Weinehall and A. Öhman. 2007. "'If I Don't Smoke, I'M Not a Real Man'-Indonesian Teenage Boys' Views about Smoking." Health Education Research 22(6):794-804 (https://www.ncbi.nlm.nih.gov/pubmed/16987943). doi: 10.1093/her/cyl104.

Sloan, Claire, Mark Conner and Brendan Gough. 2015. "How does Masculinity Impact on Health? A Quantitative Study of Masculinity and Health Behavior in a Sample of UK Men and Women." Psychology of Men \& Masculinity 16(2):206-217 (https://search.proquest.com/docview/1546223228). doi: 10.1037/a0037261.

Sobralske, Mary. 2006. "Machismo Sustains Health and Illness Beliefs of Mexican American Men." Journal of the American Academy of Nurse Practitioners 18(8):348-350 (https://doi.org/10.1111/j.1745-7599.2006.00144.x). doi: 10.1111/j.1745-7599.2006.00144.x.

Tannenbaum, Cara, and Blye Frank. 2011. "Masculinity and Health in Late Life Men." American Journal of Men's Health 5(3):243-254 (https://journals.sagepub.com/doi/full/10.1177/1557988310384609). doi: $10.1177 / 1557988310384609$.

Taywaditep, Kittiwut J. 2002. "Marginalization among the Marginalized." Journal of Homosexuality 42(1):1-28 (http://www.tandfonline.com/doi/abs/10.1300/J082v42n01_01). doi: 10.1300/J082v42n01_01. 


\begin{tabular}{|c|c|c|c|}
\hline Citation & \begin{tabular}{|l|} 
Methods \\
\end{tabular} & \begin{tabular}{|c|} 
Findings \\
\end{tabular} & Origin of Study \\
\hline $\begin{array}{l}\text { Addis, Michael E., and James R. } \\
\text { Mahalik (2003) Men, Masculinity, } \\
\text { and the Contexts of Help Seeking }\end{array}$ & $\begin{array}{l}\text { Looks at theoretical } \\
\text { framework on masculinity, } \\
\text { existing data on male } \\
\text { health seeking behavior } \\
\text { and intervening methods }\end{array}$ & $\begin{array}{l}\text { Masculinity is often what keeps } \\
\text { males from seeking help. Many of } \\
\text { the skills necessary to ask for help } \\
\text { are branded as feminine traits, such } \\
\text { as asking for help, admitting you } \\
\text { need help or relying on others are the } \\
\text { opposite of what it is to be } \\
\text { "masculine." }\end{array}$ & $\begin{array}{l}\text { Clark University } \\
\text { (Addis) \& Boston } \\
\text { College (Mahalik) } \\
\end{array}$ \\
\hline $\begin{array}{l}\text { Affleck, William, Victoria } \\
\text { Carmichael and Rob Whitley } \\
\text { (2018) Men's Mental Health: Social } \\
\text { Determinants and Implications for } \\
\text { Services }\end{array}$ & $\begin{array}{l}\text { Looks at social deterrents } \\
\text { of males who do not seek } \\
\text { mental health resources, } \\
\text { such as employment } \\
\text { issues, adverse } \\
\text { childhoods, family issues } \\
\text { and divorce and } \\
\text { parenthood. }\end{array}$ & $\begin{array}{l}\text { Males are underreported in mental } \\
\text { health rates, yet have the highest } \\
\text { rates for substance abuse and } \\
\text { suicide. Dominant notions of } \\
\text { masculinity are typically why men do } \\
\text { not seek help. They revere gender } \\
\text { ideals of hegemonic masculinity such } \\
\text { as self-relibility. If we want to reach } \\
\text { men where they live, we need to } \\
\text { unfeminize the mental health system. }\end{array}$ & Montreal, Quebec \\
\hline $\begin{array}{l}\text { Annandale, Ellen, and Kate Hunt } \\
\text { (1990) Masculinity, Femininity and } \\
\text { Sex: An Exploration of their Relative } \\
\text { Contribution to Explaining Gender } \\
\text { Differences in Health }\end{array}$ & $\begin{array}{l}\text { longitudinal study of three } \\
\text { age cohorts in Glasgow }\end{array}$ & $\begin{array}{l}\text { When looking at the self reported } \\
\text { health rates, women were more likely } \\
\text { to report poor health. One reason for } \\
\text { this is that it is more socially } \\
\text { acceptable for women to be sick. } \\
\text { Also masculinity is societally } \\
\text { rewarded, so by not reporting illness } \\
\text { males appear strong, tough and } \\
\text { manly. }\end{array}$ & Oxford, UK \\
\hline $\begin{array}{l}\text { Apesoa-Varano, Ester, Judith C. } \\
\text { Barker and Ladson Hinton (2018) } \\
\text { "If You were Like Me, You would } \\
\text { Consider it Too": Suicide, Older } \\
\text { Men, and Masculinity }\end{array}$ & $\begin{array}{l}\text { Cross-sectional, mixed } \\
\text { methods study of } 77 \text { men } \\
\text { with both treated and } \\
\text { untreated depression who } \\
\text { were age } 60 \text { and older; } \\
\text { after meeting criteria they } \\
\text { were given an interview } \\
\text { lasting between an hour to } \\
\text { two hours }\end{array}$ & $\begin{array}{l}\text { Suicide rates are higher for older age } \\
\text { men then any other age range or } \\
\text { gender, but no one asked "why" - } \\
\text { this study was trying to fill the hole } \\
\text { left in the existing literature. Most } \\
\text { males interviewed said depression } \\
\text { was linked to losing status "as a man" } \\
\text { through job loss, divorce or illness, } \\
\text { which only highlights the role of } \\
\text { hegemonic masculinity when looking } \\
\text { at suicide. }\end{array}$ & $\begin{array}{l}\text { University of } \\
\text { California }\end{array}$ \\
\hline $\begin{array}{l}\text { Cogan, A. M., C. E. Haines and M. } \\
\text { D. Devore (2019) Intersections of } \\
\text { US Military Culture, Hegemonic } \\
\text { Masculinity, and Health Care among } \\
\text { Injured Male Service Members }\end{array}$ & $\begin{array}{l}\text { Individual interviews and } \\
\text { focus groups of injured } \\
\text { U.S military service } \\
\text { members with chronic mild } \\
\text { traumatic brain injuries } \\
\text { (mTBI) were collected }\end{array}$ & $\begin{array}{l}\text { Using Bourdieu's theory of practice } \\
\text { as theoretical framework for the } \\
\text { study, the researchers saw four } \\
\text { emerging themes when it came to the } \\
\text { military members not seeking medical } \\
\text { help: Maintenance of social captial, } \\
\text { their need to remain in the field, } \\
\text { reframing of healthcare to boost } \\
\text { social capital and risk of not being } \\
\text { rewarded for seeking help. All this } \\
\text { points out the deep roots of } \\
\text { hegemonic masculinity when } \\
\text { examining military culture. }\end{array}$ & $\begin{array}{l}\text { Washington DC } \\
\text { Veterans Affairs } \\
\text { Medical Center }\end{array}$ \\
\hline
\end{tabular}




\begin{tabular}{|c|c|c|c|}
\hline \begin{tabular}{|c|} 
Citation \\
\end{tabular} & \begin{tabular}{|l|} 
Methods \\
\end{tabular} & \begin{tabular}{|c|} 
Findings \\
\end{tabular} & Origin of Study \\
\hline $\begin{array}{l}\text { Courtenay, Will H. (2000) } \\
\text { Constructions of Masculinity and } \\
\text { their Influence on Men's Well-being: } \\
\text { A Theory of Gender and Health }\end{array}$ & $\begin{array}{l}\text { Uses existing literature on } \\
\text { masculinity and femininity } \\
\text { to explore the ways as a } \\
\text { society we have socially } \\
\text { constructed ideals of } \\
\text { masculinity and how it } \\
\text { relates to health }\end{array}$ & $\begin{array}{l}\text { Men are far more likely to befall } \\
\text { illnesses, yet are more likely to adopt } \\
\text { behaviors and ideals that put them at } \\
\text { risk due to hegemonic and fragile } \\
\text { masculinity constructions within } \\
\text { society. }\end{array}$ & $\begin{array}{l}\text { Sonoma State } \\
\text { University, CA }\end{array}$ \\
\hline $\begin{array}{l}\text { Courtenay, Will H. (2011) Dying to } \\
\text { be Men Psychosocial, } \\
\text { Environmental, and Biobehavioral } \\
\text { Directions in Promoting the Health } \\
\text { of Men and Boys }\end{array}$ & $\begin{array}{l}\text { Uses four empirical studies } \\
\text { done by colleagues that } \\
\text { look at the links between } \\
\text { masculinity and men and } \\
\text { boys' health and beliefs. }\end{array}$ & $\begin{array}{l}\text { If you really want to "be a man" you } \\
\text { put yourself at great risk of disease, } \\
\text { injury or death due to masculine } \\
\text { ideals of hegemonic masculinity. Also } \\
\text { looked at are special populations of } \\
\text { men and their specific needs for } \\
\text { health, such as prison inmates and } \\
\text { college students that are male. }\end{array}$ & $\begin{array}{l}\text { Sonoma State } \\
\text { University, CA }\end{array}$ \\
\hline $\begin{array}{l}\text { Galdas, Paul M., Francine Cheater } \\
\text { and Paul Marshall (2005) Men and } \\
\text { Health Help-seeking Behaviour: } \\
\text { Literature Review }\end{array}$ & $\begin{array}{l}\text { Literature review of } \\
\text { gender specific studies } \\
\text { using multiple health } \\
\text { centered databases }\end{array}$ & $\begin{array}{l}\text { Highlights trend of men's delayed } \\
\text { help seeking when they beome ill and } \\
\text { looks at masculine beliefs and } \\
\text { similarites and differences between } \\
\text { men of differing backgrounds. }\end{array}$ & $\begin{array}{l}\text { University of } \\
\text { Leeds, Yorkshire, } \\
\text { UK }\end{array}$ \\
\hline $\begin{array}{l}\text { Gast, Julie, and Terry Peak (2011) } \\
\text { It used to be that if it Weren't } \\
\text { Broken and Bleeding Profusely, I } \\
\text { would Never Go to the Doctor }\end{array}$ & $\begin{array}{l}\text { Looked at focus groups of } \\
\text { males involved in church }\end{array}$ & $\begin{array}{l}\text { Males use gender scripts and gender } \\
\text { norms when responding to health } \\
\text { issues. In a health setting this means } \\
\text { they do not show weakness or } \\
\text { vulnerability. They also show } \\
\text { machismo, or an overcompensation } \\
\text { of masculinity by involving } \\
\text { themselves in risky behaviors they } \\
\text { deem to be "traditionally masculine" } \\
\text { such as physical fighting, alcohol } \\
\text { abuse, not being able to manage } \\
\text { anger and avoiding health screenings. }\end{array}$ & $\begin{array}{l}\text { Utah State } \\
\text { University }\end{array}$ \\
\hline $\begin{array}{l}\text { Hoy, S. (2012) Beyond Men } \\
\text { Behaving Badly: A Meta- } \\
\text { Ethnography of Men's Perspectives } \\
\text { on Psychological Distress and Help } \\
\text { Seeking }\end{array}$ & $\begin{array}{l}\text { Meta-ethnography was } \\
\text { conducted on } 51 \\
\text { qualitative studies on mens' } \\
\text { perspectives of } \\
\text { psychological distress and } \\
\text { help-seeking behavior }\end{array}$ & $\begin{array}{l}\text { Masculinity negatively impacts mental } \\
\text { health and is a barrier for males. }\end{array}$ & Ontario, Canada \\
\hline $\begin{array}{l}\text { Kimmel, M. S., and M. Mahler } \\
\text { (2003) Adolescent Masculinity, } \\
\text { Homophobia, and Violence: } \\
\text { Random School Shootings, 1982- } \\
2001\end{array}$ & Existing literature & $\begin{array}{l}\text { One common theme among all } \\
\text { school shootings in this time period } \\
\text { was masculinity, specifically the } \\
\text { constellation of adolescent } \\
\text { masculinity }\end{array}$ & $\begin{array}{l}\text { State University of } \\
\text { New York at } \\
\text { Stony Brook }\end{array}$ \\
\hline $\begin{array}{l}\text { Knight, Rod, Jean A. Shoveller, } \\
\text { John L. Oliffe, Mark Gilbert, Blye } \\
\text { Frank and Gina Ogilvie (2012) } \\
\text { Masculinities, 'guy Talk' and } \\
\text { 'manning Up': A Discourse Analysis } \\
\text { of how Young Men Talk about } \\
\text { Sexual Health }\end{array}$ & $\begin{array}{l}32 \text { in-depth interviews } \\
\text { with } 15-24 \text {-year-old men } \\
\text { about sexual health }\end{array}$ & $\begin{array}{l}\text { Sexually transmitted disease testing } \\
\text { of males is low as is their use of } \\
\text { sexual health services. Most report } \\
\text { that they shut down communication } \\
\text { when it comes to sexual health with } \\
\text { peers and instead use masculine } \\
\text { scripts to describe sexual encounters } \\
\text { in which they have all the power. }\end{array}$ & $\begin{array}{l}\text { British Columbia, } \\
\text { Canada }\end{array}$ \\
\hline
\end{tabular}




\begin{tabular}{|c|c|c|c|}
\hline Citation & Methods & Findings & Origin of Study \\
\hline $\begin{array}{l}\text { Kumpula, Esa, and Per Ekstrand } \\
\text { (2014) Challenges and Possibilities } \\
\text { for Understanding Men's Health in } \\
\text { Twenty-First Century Forensic } \\
\text { Psychiatric Care }\end{array}$ & \begin{tabular}{|l|} 
Existing literature and \\
studies of forensic \\
psychiatric care in Sweden
\end{tabular} & $\begin{array}{l}\text { Mens' relationship to health is based } \\
\text { on their perception of masculinity, } \\
\text { and power is a factor. }\end{array}$ & Sweden \\
\hline $\begin{array}{l}\text { Kvigne, Kari, Marit Kirkevold, } \\
\text { Randi Martinsen and Berit A. } \\
\text { Bronken (2014) Masculinity and } \\
\text { Strokes: The Challenges Presented } \\
\text { to Younger Men by Chronic Illness }\end{array}$ & \begin{tabular}{|l|} 
Florey Adelaide Male \\
Ageing Study (FAMAS) \\
was used as was Likert \\
scales to develop a \\
measurement for masculine \\
beliefs
\end{tabular} & $\begin{array}{l}\text { Sexual health and age were sensitive } \\
\text { to masculinity and should be looked } \\
\text { at more thoroughly }\end{array}$ & Austrailia \\
\hline $\begin{array}{l}\text { Mahalik, James R., W. T. } \\
\text { Talmadge, Benjamin D. Locke and } \\
\text { Ryan P. J. Scott (2005) Using the } \\
\text { Conformity to Masculine Norms } \\
\text { Inventory to Work with Men in a } \\
\text { Clinical Setting }\end{array}$ & $\begin{array}{l}\text { Male therapy client studies } \\
\text { using the Conformity to } \\
\text { Masculine } \\
\text { Norms Inventory (CMNI) }\end{array}$ & $\begin{array}{l}\text { Males who conform to masculine } \\
\text { beliefs have both benefits and costs, } \\
\text { but typically the costs are to people } \\
\text { close and not the male. The more } \\
\text { conformity, the greater the benefit is } \\
\text { to males. }\end{array}$ & Boston College \\
\hline $\begin{array}{l}\text { Mansfield, Abigail K., Michael E. } \\
\text { Addis and James R. Mahalik }\end{array}$ & Existing literature & $\begin{array}{l}\text { Groupthink influences a male's } \\
\text { likliness of seeking help, as does } \\
\text { Asch's conformity theory. A male } \\
\text { will not seek help if the majority of } \\
\text { people in his life are against it. If he } \\
\text { feels stigmatized, he will not seek } \\
\text { help. Few attempts have been made } \\
\text { to advance us in male help-seeking. }\end{array}$ & United States \\
\hline Moynihan, Clare (1998) Theories of & Existing literature & $\begin{array}{l}\text { Highly masculine reporting men } \\
\text { underreport illness. When looking at } \\
\text { emotions they should be presenting, } \\
\text { they hide them. Because so many } \\
\text { health questionnaires are self- } \\
\text { reported with no one to watch and } \\
\text { check reliability, most are not valid } \\
\text { due to contradictions in reporting. It } \\
\text { is only by looking at alternative } \\
\text { masculine theories instead of } \\
\text { traditional ones that we can see } \\
\text { information is skewed. }\end{array}$ & Great Britian, UK \\
\hline $\begin{array}{l}\text { Möller-Leimkühler, Anne M. } \\
\text { (2002) Barriers to Help-Seeking by } \\
\text { Men: A Review of Sociocultural and } \\
\text { Clinical Literature with Particular } \\
\text { Reference to Depression }\end{array}$ & Literature review & $\begin{array}{l}\text { Social norms of masculinity create a } \\
\text { barrier for males to seek help. They } \\
\text { are underreported especially in } \\
\text { mental health services even though } \\
\text { they are at a greater risk then women } \\
\text { to suffer a mental health episode. } \\
\text { This can be attributed to cultural and } \\
\text { societal creation of masculinity } \\
\text { scripts. }\end{array}$ & Munich, Germany \\
\hline
\end{tabular}




\begin{tabular}{|c|c|c|c|}
\hline Citation & \begin{tabular}{|c|} 
Methods \\
\end{tabular} & \begin{tabular}{|c|} 
Findings \\
\end{tabular} & Origin of Study \\
\hline $\begin{array}{l}\text { Ng, Nawi, L. Weinehall and A. } \\
\text { Öhman (2006) If I Don't Smoke, } \\
\text { I'm Not a Real man'-Indonesian } \\
\text { Teenage Boys' Views about } \\
\text { Smoking }\end{array}$ & $\begin{array}{l}\text { Six focus group } \\
\text { discussions with boys aged } \\
13-17 \text { years of age were } \\
\text { conducted using a thematic } \\
\text { discussion guide. }\end{array}$ & $\begin{array}{l}\text { Four themes were found- Culture } \\
\text { made it a habit, smoking isn't that } \\
\text { dangerous, it's how I become a man } \\
\text { and struggling against dependency. } \\
\text { Most boys beliefs were tied up in the } \\
\text { cultural structure of smoking = } \\
\text { manliness. In Indonesia, such risk } \\
\text { taking behavior is not allowed for } \\
\text { women, as women are not } \\
\text { normalized to smoke }\end{array}$ & Indonesia \\
\hline $\begin{array}{l}\text { Sloan, Claire, Mark Conner and } \\
\text { Brendan Gough (2015) How does } \\
\text { Masculinity Impact on Health? A } \\
\text { Quantitative Study of Masculinity } \\
\text { and Health Behavior in a Sample of } \\
\text { UK Men and Women }\end{array}$ & $\begin{array}{l}\text { Quantitative study of } \\
\text { masculinity using } 182 \text { men } \\
\text { and } 274 \text { women who self- } \\
\text { reported health behaviors }\end{array}$ & $\begin{array}{l}\text { Males with high masculinity traits } \\
\text { scored higher on negative health } \\
\text { behaviors and lower on positive } \\
\text { health behaviors. }\end{array}$ & $\begin{array}{l}\text { University of } \\
\text { Leeds, Yorkshire, } \\
\text { UK }\end{array}$ \\
\hline $\begin{array}{l}\text { Sobralske, Mary. (2006) Machismo } \\
\text { sustains health and illness beliefs of } \\
\text { Mexican American men }\end{array}$ & Existing Literature & $\begin{array}{l}\text { Mexican males are taught to have } \\
\text { machismo, which translates to } \\
\text { manliness in English. It is important to } \\
\text { note this when looking at health, a } \\
\text { man's health beliefs and behaviors } \\
\text { are reflected in how he views himself } \\
\text { in society. Culture and health are } \\
\text { closely linked. }\end{array}$ & Honolulu, Hawaii \\
\hline $\begin{array}{l}\text { Tannenbaum, Cara, and Blye Frank } \\
\text { (2011) Masculinity and Health in } \\
\text { Late Life Men }\end{array}$ & $\begin{array}{l}\text { Two studies were looked } \\
\text { at - the first being a } \\
\text { qualitative study of a focus } \\
\text { group discussion with } 48 \\
\text { older men. The second } \\
\text { was a mailed survey to } \\
\text { more than } 2000 \text { men aged } \\
55 \text { to } 97 \text { on health } \\
\text { behaviors and masculinity. }\end{array}$ & $\begin{array}{l}\text { Males have to negotiate hegemonic } \\
\text { masculinity in later life. With age men } \\
\text { will seek help even if it conflicts with } \\
\text { hegemonic attitudes if it threatens } \\
\text { their independence. }\end{array}$ & Canada \\
\hline $\begin{array}{l}\text { Taywaditep, Kittiwut Jod (2002) } \\
\text { Marginalization Among the } \\
\text { Marginalized }\end{array}$ & Existing Literature & $\begin{array}{l}\text { Even among gay males, hegemonic } \\
\text { attitudes are prevalent. Anti- } \\
\text { effeminacy beliefs are the norm and } \\
\text { this is due to the hegemonic attitude } \\
\text { that men are superior to women. }\end{array}$ & $\begin{array}{l}\text { University of } \\
\text { Illinois at Chicago }\end{array}$ \\
\hline
\end{tabular}

